\title{
VARIABILIDADE DE ppGpp ENTRE GENÓTIPOS DE ESCHERICHIA COLI PRODUTORA DE TOXINAS SHIGA (STEC)
}

\author{
VARIABILITY OF ppGpp IN SHIGA-LIKE TOXIN-PRODUCING \\ Escherichia coli (STEC)
}

A. E. STELLA ${ }^{1 *}$, B. SPIRA ${ }^{2}$

\begin{abstract}
RESUMO
Objetivos: $\mathrm{O}$ alarmônio ppGpp acumula-se em bactérias submetidas a estresses nutricionais, tais como a limitação de aminoácidos, carbono ou fosfato e também em bactérias submetidas a estresses ambientais. O acúmulo de ppGpp provoca a resposta severa, caracterizada por uma radical diminuição na síntese de ribossomos e proteínas, impedindo o crescimento bacteriano. A capacidade dos agentes patogénicos causadores de doenças alimentares sobreviver em certos alimentos depende de seus mecanismos de resposta ao estresse, neste sentido foi objetivo deste estudo avaliar a variabilidade da produção de ppGpp em isolados STEC de diferentes perfis stx ${ }^{+}$. Material e Método: Foi avaliada a produção de ppGpp em 33 cepas STEC. As bactérias foram cultivadas em meio mínimo, após este prazo, alíquotas foram retiradas e misturadas a volumes iguais de $2 \mathrm{M}$ de ácido fórmico. $\mathrm{O}$ extrato celular foi aplicado a placas de cromatografia. O extrato foi resolvido colocando as placas em uma câmara de cromatografia contendo 1.5 M KH2PO4 (pH 3.4) como solvente e analisada em um Phosphor-Imager. A quantidade de ppGpp foi estimada através da medição de radioatividade dos spots. Resultados: Em média, as cepas stxl apresentaram um nível de ppGpp de 0,25 unidades, as stxl+stx2 0,28 unidades e as stx2 0,36 unidades. Ou seja, as STEC que carregam apenas stx2 apresentaram em média pelo menos $30 \%$ a mais de ppGpp que as cepas dos demais grupos. Em se tratando de ppGpp, essa diferença não é desprezível. Podemos observar uma tendência de que isolados do perfil genotípico $s t x 2$ produzem níveis maiores de ppGpp que isolados do perfil stxl, enquanto que o perfil stxl+stx2 é mais heterogêneo quanto a concentração de ppGpp. Conclusão: Observamos níveis variáveis de ppGpp, evidenciando um considerável polimorfismo nas cepas STEC avaliadas.
\end{abstract}

PALAVRAS-CHAVE: SIGMA S. ESTRESSE. VIRULÊNCIA.

AGRADECIMENTOS: FAPESP

ÁREA TEMÁTICA: Doenças Infecciosas 